\title{
Piotr Barczak
}

\section{Synergia w firmie rodzinnej, czyli dlaczego $2+2=4$ a nie 5}

Streszczenie: Pojęcie synergii opisywane jest w wielu naukach. Określenie to niekoniecznie oznacza zwiększone efekty działań wspólnych. Synergia charakteryzuje proces samoorganizacji $\mathrm{w}$ ramach ograniczonych zasobów. Jej występowanie determinowane jest przez granicę chaosu, a działania innowacyjne pozwalają ją przekroczyć. Małe firmy rodzinne podlegają prawom fizyki i termodynamiki. Autor $\mathrm{w}$ przeprowadzonym eksperymencie stawia hipotezę, że jednym z ograniczonych zasobów chronionym przez przedsiębiorców, może być ich wspólna energia życiowa.

Słowa kluczowe: synergia, synergizm, firmy rodzinne, ograniczone zasoby, społeczne próżniactwo, samoorganizacja

Synergy in a family business, i.e. why $2+2=4$ and not 5

Summary: TThe concept of synergy is described in many different branches of science. It does not necessarily mean increasing effects as a result of joint actions. It involves process of self-organization in terms of limited resources. Its occurrence is determined by the boundaries of chaos, and innovative actions allow to overcome barriers. Small businesses fall under the general laws of physics and thermodynamics. The author in the experiment puts the hypothesis, that one of the limited resources protected by entrepreneurs is the lifesource energy.

Keywords: synergy, synergetics, self-organization, limited resources, social loafing, family business

JEL D500, D200, D210, I120, P420

Określenie synergia stało się pojęciem potocznym. Często używane jest w naukach społecznych, zarządzaniu czy farmacji. Niekiedy jednak słowo to jest nadużywane, biorąc pod uwage fakt, że ostatecznie nie sprecyzowano definicji synergii. Trudność $w$ rozwikłaniu tego zagadnienia polega na tym, że dotyczy ono wielu dziedzin nauki i jest określeniem wielowymiarowym.
Pojęciem synergii, często posługują się ekonomiści uzasadniając koncepcję, że wspólny wysiłek pozwala osiągnąć wyższe efekty niż praca indywidualna poszczególnych osób. Wymyślono nawet hasło, że $2+2$ nie równa się 4 a 5, chcąc zobrazować funkcjonowanie modelu synergii. Jak wiadomo, z punktu widzenia matematyki tego typu równanie nie jest prawdziwe. 


\section{Meandry definicji synergia}

Etymologia słowa synergia nawiązuje do słowa synergos oznaczającego współpracujący a szerzej - współdziałający. Arystoteles twierdził, że całość to więcej niż suma całości, choć w swoich rozważaniach nawiązywał do pojęć substancja, energia (gr. energeia), ruch (gr. kinêsis). Według niego, zbudowany stół to więcej niż tylko drewno, z którego został stworzony. Współcześni filozofowie opisywali zjawisko synergii szerzej, wskazując, że jeśli podmioty współpracujące osiągną więcej niż każdy z osobna to mamy do czynienia ze zjawiskiem synergii. Pojęcie Arystotelesa zostało rozwinięte, a synergia stała się odmiennym bytem pojęciowym.

Ekonomiści używają pojęcia synergii dość często, starając się wyjaśnić jeden ze sposobów osiągania efektu organizacyjnego, w wyniku którego uzyskuje się nadwyżkę korzyści przypadającej na członka zespołu, jeśli współdziała on w sposób zorganizowany w ramach instytucji, w porównaniu z korzyścią jaką mógłby osiągnąć działając w pojedynkę - przy założeniu maksymalnego możliwego $\mathrm{w}$ każdym z tych przypadków stopnia zorganizowania działania indywidualnego (Zieleniewski, 1982).

Pojęcia współpraca, kooperacja, synergia, w gąszczu licznych definicji zaczynają się wzajemnie przeplatać, gdyż ciągle ostatecznie nie sprecyzowano pojęcia synergii. Przykładowo, w encyklopedii zarządzania: synergia współpracy rynkowej to współdziałanie, kooperacja, w wyniku czego, poprzez wspólne działania uzyskuje się zwiększone efekty i uzyskuje obniżenie kosztów. W tekstach logistycznych, kooperacja to jednak porozumienie między podmiotami, na mocy którego następuje podział lub uzupełnienie pracy, a uzgodnienia nabierają mocy prawnej przez podpisanie umowy (Krawczyk, 2011). Kooperacja nie oznacza zwiększonych efektów współpracy.
Kolejnym pojęciem, w którym nawiązuje się do synergii jest symbioza. Definicja symbiozy różni się od pojęcia synergia, gdyż symbioza to okresowe lub stałe współżycie dwóch organizmów różnych gatunków, przynoszące korzyść co najmniej jednemu z nich, a nieprzynoszące szkód żadnemu. Nie widać w tym przypadku żadnych efektów dodatkowych, żadnej sumy łącznej, większej niż sumy pojedynczych korzyści.

Według P. Corninga, synergia odnosi się do połączonych efektów wszelkiego rodzaju, przy czym efekty te mogą być wyższe, neutralne lub mniejsze niż suma pojedynczych działań (Corning,1998). Czy tego typu ujęcie synergii nie jest jednak mylące? W takim przypadku zapominamy o podstawach utworzenia słowa synergia, wywodzącego się od Arystotelesa (całość to więcej niż suma całości), a także pomijamy podstawowe definicje z zakresu zarządzania.

Synergia według R.W. Griffina występuje wtedy, gdy dwa lub więcej z podsystemów produkują więcej, niż wynosi łączna suma produkcji każdego z nich, gdyby pracowały osobno (Griffin, 2006). $\mathrm{Z}$ kolei w pracach naukowych $\mathrm{z}$ zakresu logistyki, efekt synergii rozumiany jest jako odpowiedni dobór partnerów, pozwalający wykorzystywać ich kluczowe kompetencje, dzięki czemu oszczędza się czas i koszty (Krawczyk, 2011).

Gdyby przyjąć za ostateczną definicję P. Corninga, to synergią są wszystkie zjawiska, w wyniku których powstaje cokolwiek. Synergią będą procesy zachodzące w lawinach, gdyż w wyniku wewnętrznych transformacji tworzą się procesy lawinowe. Przekształcenie wody w lód to też synergia. Symbioza roślin to również synergia. Synergia według R.W. Griffina oznacza wyłącznie, że jednostki organizacyjne mogą często działać skuteczniej, kiedy pracują razem, niż kiedy pracują oddzielnie. 
Synergia to pojęcie, które budzi kontrowersje. Przeprowadzone analizy ukazały, że synergii nie zawsze towarzyszy poprawa rentowności. Nie można wiązać w sposób linearny synergii i rentowności. Łączenie jednostek biznesowych w firmach nie zawsze wywołuje wzrost rentowności. Niekiedy, po połączeniu firm nawet się ona obniża (Vijay, et al., 1988). Również synergie finansowe przy łączeniu firm nie zawsze są korzystne (Leland, 2007).

\section{Społeczne próżniactwo,} innowacje, synergia

Warto wspomnieć, co nie jest synergią. Nie jest nią podział sił rozkładających się np. na każdą z czterech nóg stołu, jeśli na stole położymy ciężarek F. Po położeniu na blacie stołu ciężaru F otrzymujemy cztery siły F1, F2, F3, F4, a więc ciężar rozkłada się równo na każdą $\mathrm{z}$ nóg. Tego typu podział nie ma nic wspólnego z synergią.

Również warto wskazać, że statyka również przeczy idei synergii rozumianej, jako $2+2=5$. To właśnie prawa statyki zaprzeczają, by wśród elementów niematerialnych istniała synergia. Wystarczy spojrzeć na prosty układ graficzny sił statycznych (rys.1). Wynika z niego, że wysiłek dwóch sił, siły A i siły $B$, generuje siłę o maksymalnej wypadkowej sił C. Długość wypadkowej $\mathrm{C}$ nigdy jednak nie daje równania $2+2=5$. Fizyka zaprzecza takiemu ujęciu zagadnienia.

Wypadkowa dwóch sił A i B, nigdy nie jest nawet sumą sił $\mathrm{A}$ i $\mathrm{B}$, nie mówiąc o jej podwojeniu lub ich zwielokrotnieniu. Aksjomat praw statyki mówi, że wypadkowa dwóch sił przechodzi przez ich punkt przecięcia i wyraża się długością przekątnej równoległoboku zbudowanego na tych siłach, czyli wektorową wypadkową dwóch sił. Ten przykład jest zaprzeczeniem „definicji” $2+2=5$. Odwracalne reakcje chemiczne również udowadniają, że istnieje wspólny model procesów re- akcji chemicznych, w których działa stan równowagi i przynajmniej teoretycznie zawsze reakcje chemiczne są odwracalne. Nie istnieje żadna reakcja chemiczna potwierdzająca $2+2=5$. Każda reakcja chemiczna jest dwuetapowa i zachodzi według schematu $\mathrm{A} \rightarrow \mathrm{P}$ i $\mathrm{P} \rightarrow \mathrm{A}$ (Jędrusiak, 2017).

Wątpliwości odnośnie hasła $2+2=5$ pojawiły się już dawno. W 1913 roku przeprowadzono analizy efektu synergicznego. Efekt M. Ringelmanna wykazał, że w przypadku zwiększania się grupy, poszczególni członkowie zespołu stawali się coraz mniej produktywni. Efekt ilustrował odwrotną zależność między wielkością grupy a efektywnością indywidualnych członków grupy w realizowanym zadaniu. Faktycznie okazywało się, że członkowie grupy przeznaczali mniej wysiłku razem niż każdy osobno. Ten eksperyment wykazał, że działanie w grupie nie zwiększa wysiłku poszczególnych osób, a wręcz odwrotnie, obserwowane jest zjawisko utraty motywacji (Ringelmann, 1913). Warto jednak zauważyć, że tego typu zjawisko zostało scharakteryzowane na podstawie eksperymentu z przeciąganiem liny, czyli siłowego, ewentualnie analizowano kwestie techniczne czy sposoby przeciągania liny.

Zagadnienie społecznego próżniactwa było analizowane również $\mathrm{w}$ innych aspektach. Badano zaangażowanie osób krzyczących razem i osobno. Okazało się, że w wyniku krzyku grupowego, wydaj-

\section{Rysunek 1 Statyka, działanie sił,}

\section{wypadkowa sił}

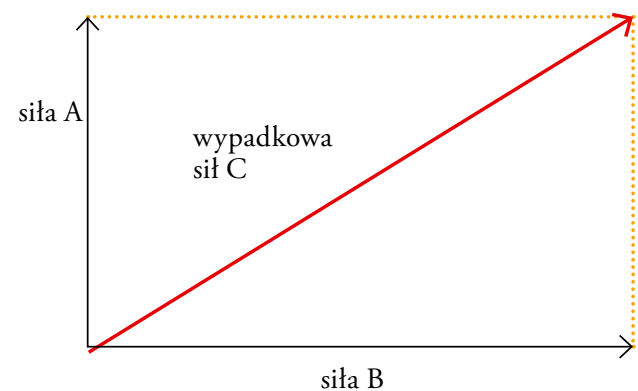

Źródło: opracowanie własne. 


\section{Rysunek 2 Społeczne próżniactwo}

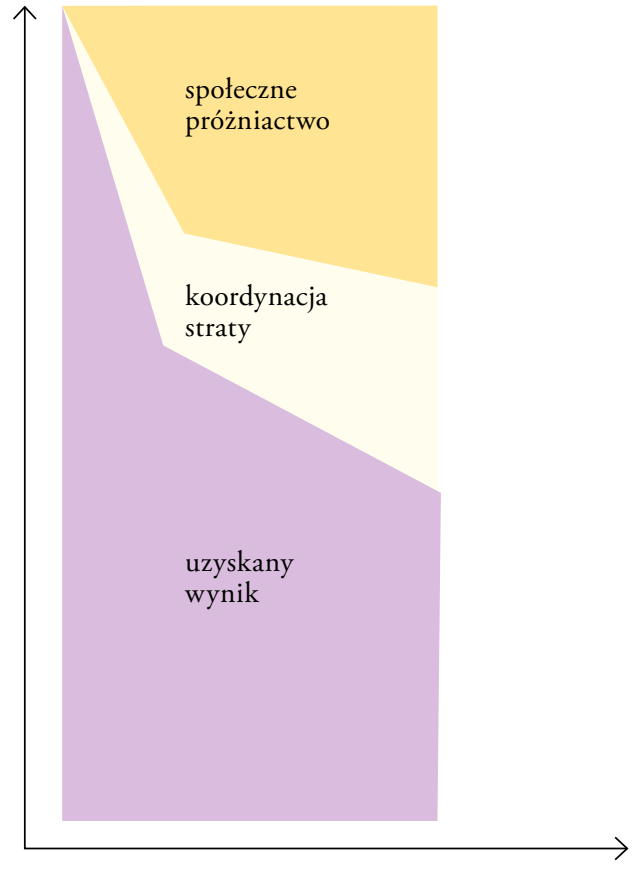

Źródło: Williams K., Harkins S., Latane B., Identifability as a Deterrent to Social Loafing: Two Cheering Experiments, "Journal of Personality and Social Psychology”,1981, Vol. 40, No. 2, 306.

ność mierzona w decybelach poszczególnych osób spadała w stosunku do wysiłku wkładanego indywidualnie. W parach wydajność spadała do 59 proc. potencjału indywidualnego, a w grupach sześcioosobowych do 31 proc. (Williams, et al., 1981).

\section{Eksperyment z wagą}

Tego typu analizy potwierdza również prosty eksperyment, wykonany przez autora, przy użyciu wagi hakowej/walizkowej z wyświetlaczem cyfrowym, podającym udźwig do $50 \mathrm{~kg}$ z dokładnością do 10 g. Waga ma plastikowy praktyczny uchwyt pozwalający utrzymywać całość wagi i metalowy hak, na którym zawiesza się walizkę lub inny ciężar. W eksperymencie wzięły udział dwa małżeństwa A i B. Poproszono je, aby każda z par wspólnie naciskała lewymi kciukami na metalowy hak wagi. Najpierw badani napierali hak indywidualnie lewym kciukiem, po wykonaniu tego zadania informowani byli o potrzebie wspólnego naciśnięcia kciukami na hak wagi.
Próba 1. Wykonana w pozycji siedzącej przez małżeństwo A: kobieta - samodzielny nacisk lewym kciukiem 4,1 kg mężczyzna - samodzielny nacisk lewym kciukiem $7,6 \mathrm{~kg}$ wspólny nacisk kobiety i mężczyzny $8,4 \mathrm{~kg}$

Próba 2. Wykonana w pozycji stojącej przez małżeństwo B: kobieta - samodzielny nacisk lewym kciukiem 9,3 kg mężczyzna - samodzielny nacisk lewym kciukiem 18,2 kg wspólny nacisk kobiety i mężczyzny $21,1 \mathrm{~kg}$

Wynik potwierdza efekt M. Ringelmanna - wspólny nacisk na metalowy hak był mniejszy w przypadku dwóch osób niż każdej osobno. W obu próbach powstał efekt społecznego próżniactwa. Przeprowadzono kolejną próbę $\mathrm{z}$ wagą walizkową z małżeństwem B, które osiągnęło wynik nacisku lewymi kciukami na hak 21,1 kg. Po sugestii motywacyjnej, wyjaśnieniu celu badania, wskazania, że potrzebna jest większa motywacja, małżeństwo B osiągnęło lepszy wynik niż przy pierwszej próbie, tj. 24,1 kg. Rezultat poprawiony jednak tylko o $3 \mathrm{~kg}$, nie przekroczył sumy wcześniej osiągniętych indywidualnych efektów.

\section{Prekursorzy pojęcia synergia}

N.A. Berstein poszukiwał synergii $\mathrm{w}$ elementach anatomicznych człowieka. Synergia była rozumiana w kontekście funkcjonowania organizmu kręgowców, w tym najszerzej człowieka. Opisując organizm człowieka Berstein zauważył, że funkcjonuje on dzięki ekonomicznemu dostarczaniu do systemu energii oraz koordynacji i kontroli systemu nerwowego nad całością poszczególnych osób. Synergia jest rozumiana przez autora jako rodzaj koordynacji, gdzie centralny układ nerwowy pełni kontrolę nad mięśniami 
człowieka. Mięśnie uczestniczą w procesie synergicznym. Według niego, każdy zespół mięśni jest elastyczny i specyficzny, zespoły pełnią funkcję samoorganizujących się jednostek, są lokalnie sprzężone i ograniczające się wewnętrznie, minimalizujące potrzebę kontrolerów $\mathrm{w}$ organizmie (Turvey, Latash, et al., 1996).

Według M.L. Latasha, są trzy elementy wpływające na synergię. Pierwszy to zależność od zadania (task-dependence), co oznacza, że w ramach pojęcia synergia mieści się cecha zmiany pewnej rzeczywistości, ręka może odkręcić wieczko, pisać przy pomocy pióra, grać utwory muzyczne, machać na pożegnanie. Grupa robotników przy pomocy rąk może budować domy, orkiestra odgrywać utwory muzyczne. Rzeczy martwe takich działań nie mogą podjąć same z siebie, natomiast wszelkie zachowania człowieka w stosunku do rzeczy martwych mogą wywoływać działania synergiczne. Synergia oznacza też „pracę wspólną”, która prowadzi do celu. Synergia to wspólne korzystanie $\mathrm{z}$ zasobów (sharing). Jeśli ludzka ręka wykonuje działanie, to palce generują siły. Palce ludzkie mają odpowiednio podzielone działania. Podobnie z zespołami ludzkimi.

Kolejny czynnik to kompensacja błędu (error compensation). Jeśli wyznaczone zadanie jest wykonywane wspólnie, a jeden z elementów odstaje od reszty, pozostałe fragmenty dążą do wyrównania błędu, tak aby osiągnąć zakładany cel (Latash, 2008). Autor traktuje synergię jako pojęcie dotyczące ograniczonych zasobów, dzięki któremu można zmienić jakościowo istniejący stan.

Synergetyka stała się obszarem badań, którym zajął się zespół H. Hakena. Dostrzegł on zjawisko samoorganizacji występujące w przeróżnych systemach. Zauważył, że komponenty plazmy dążą do samoregulacji. Posługiwał się określeniem synergizmu. Synergizm to jednak nie synergia rozumiana przez ekonomistów jako powstawanie pewnej nadwyżki wynikającej z pozytywnej współpracy. Synergizm to opis zjawisk samoregulacji, samoorganizacji, wynikającej z istniejących praw termodynamiki (Haken, 1983). Według niego, synergetyka to układ systemowy składający się z wielu subsystemów mających zróżnicowany charakter, takich jak elektrony, atomy, komórki, molekuły, neurony, fotony, poszczególne organy człowieka, organizmy całych zwierząt lub ludzi. Zatem system to kooperacja subsystemów, które poprzez wzajemne uwarunkowania kreują funkcjonowanie makroskopowych struktur. Subsystemy wywołują samoorganizację systemów, a zasady synergizmu są uniwersalnie obowiązujące $\mathrm{w}$ przyrodzie, $\mathrm{w}$ tym $\mathrm{w}$ świecie fizyki, termodynamiki, socjologii i ekonomii.

Takie ujęcie jest tożsame $\mathrm{z}$ definicją systemu, która nawiązuje do greckiego słowa systema, oznaczającego rzecz złożoną, wzajemnie powiązanych elementów, działających jako całość. Całość powiązana poprzez relacje funkcjonuje jako układ samoregulujący, dążący do równowagi. Haken uznaje mózg za jeden spójny, skoordynowany system. Mózg składa się ze 100 miliardów neuronów $\left(10^{11}\right)$ i jest możliwe istnienie $10^{4}$ połączeń na poszczególny neuron. W takim kontekście, każdy neuron jest oddzielnym systemem. Problemem jest jednak stworzenie równań matematycznych odwzorowujących procesy biologiczne i przekładanie ich na procesy fizyczne. Jeden neuron wykonuje

\section{Rysunek 3 Cechy synergii}

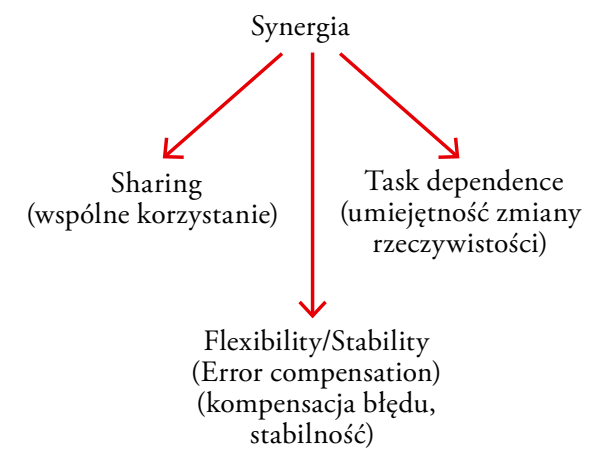

Źródło: Mark L. Latash, Synergy, Oxford University Press, 2008, NY, p. 15. 


\section{Rysunek 4 Samoorganizacja grup}

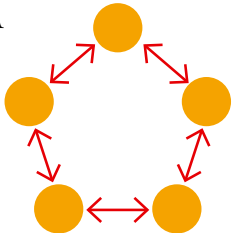

$\mathrm{B}$

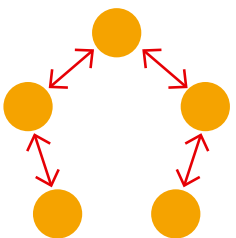

C

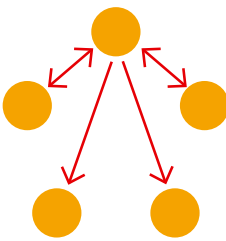

Źródło: H. von Foerster, Principles of Self-Organization-In a Socio-Managerial Context, Springer, 1984.

miliony operacji, trudno więc stwierdzić, czy neuron to jeden z elementów systemu (subsystem) czy osobny niezależny system. Podlega on jednak prawom fizyki (Haken, 1996). W każdej sytuacji następuje dążenie układu do wykorzystywania jak najniższej energii wewnętrznej. Układy materialne znane z fizyki i chemii ulegają przekształceniom. $Z$ pierwiastka jakim jest np. węgiel może powstać grafit lub diament, niekiedy sadza. Takie przekształcenia $\mathrm{w}$ pewnym sensie przypominają synergię, następuje np. samoorganizacja pierwiastków (krystalizacja). Termodynamika kształtuje świat przyrody, ale również niektórych aspektów mikroekonomii.

Zjawisko samoorganizacji występuje w grupach ludzi. Podjęto próby analizy osób działających w grupach. Badani mogli się wzajemnie informować poprzez przeka-

\section{Rysunek 5 Liczba firm mikro, małych, średnich, dużych}

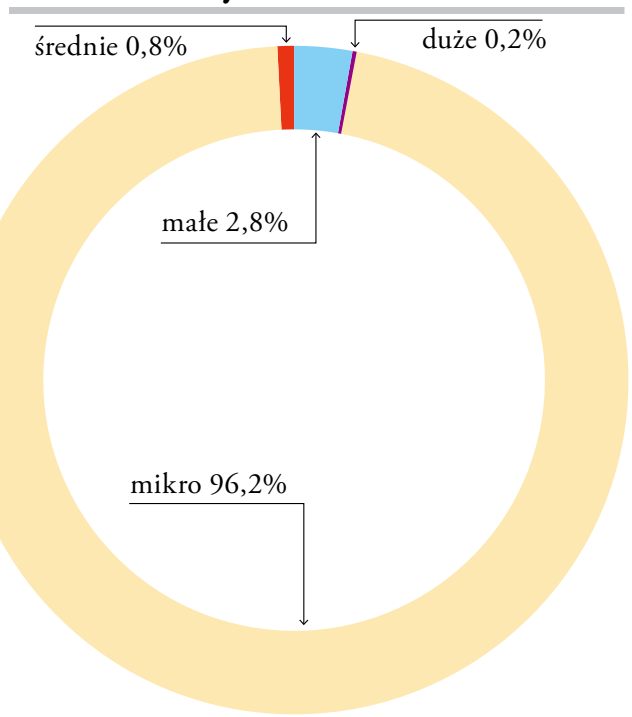

Źródło: Raport o stanie sektora matych i średnich przedsiębiorstw w Polsce, A. Skowrońska, A. Tarnawa (red.), PARP, grupa PFR, Warszawa, czerwiec 2018. zywanie informacji w formie pisemnej, a chodziło o poznanie pisanych w notatnikach symboli. Jeśli symbol rozpoznano prawidłowo, naciskano na przycisk. W wariancie $\mathrm{A}$ nie określono lidera. $\mathrm{Z}$ kolei w wariancie $\mathrm{C}$, narzucony przez badającego lider budził agresję wśród członków zespołu, mimo że zespół C wykonywał zadanie w podobnym czasie jak zespół A. $\mathrm{Z}$ czasem takie zespoły się rozpadają. Po wprowadzeniu możliwości komunikowania się, rozmów, grupa A - samoorganizująca się, rozwijała się, a komunikacja służyła umocnieniu przekazu i więzi. Grupa C się rozpadła. Tego typu eksperymenty mogą potwierdzać występowanie zjawiska samoorganizacji grup ludzkich. Działanie niewielkich grup ludzkich może obrazować zasady synergizmu.

Przykładem jednostki samoorganizującej może być mała firma. Zarządza własnymi, ograniczonymi środkami finansowymi, tworzą ją niewielkie grupy ludzkie, z reguły kilka osób. Najpopularniejszą formą działalności gospodarczej jest mikrofirma.

Mała firma rodzinna to również praca zespołowa. W ramach takich działań kształtowana jest tożsamość firmy, tworzone są specyficzne wartości, które identyfikują grupę. W ramach grupy następuje wymiana wiedzy i wzajemne nabywanie doświadczenia. Kształtuje się poczucie wspólnoty i lojalności (Leszczewska, Sobiecki, 2011). Wzajemne relacje są istotą funkcjonowania. Praca zespołowa umacnia system i strukturę organizacji. Dzięki temu również samoorganizuje się. Tworzy się równowaga w grupie. 
W Polsce 96,2 proc. firm to mikrofirmy, zatrudniające do 9 pracowników. Co ciekawe, w przeciętnej takiej firmie pracuje średnio 4,8 osób, a taki podmiot gospodarczy zatrudnia średnio 3,4 osoby - dane za 2016 r. (Skowrońska, Tarnawa, 2018). Wydaje się, że tego typu jednostka organizacyjna jest najefektywniejsza w lokalnym środowisku gospodarczym i najlepiej wykorzystuje dostępne wspólne zasoby. Działania synergiczne mogą osiągać najwyższą efektywność, a społeczne próżniactwo może mieć najniższą wartość. Można też postawić tezę, że taka grupa również najlepiej się samoorganizuje.

\section{Synergia, ograniczone zasoby}

\section{a potrzeba działań wspólnych}

Synergia dotyczy samoorganizacji i działania w obszarach ograniczonych zasobów, a zachowanie całości systemu nie może być rozpatrywane na podstawie elementów indywidualnych (Fuller, et al., 1975). W takim ujęciu istnieją określone granice zasobów, a przekroczenie ich powoduje dezorganizację i chaos. Własne zasoby można zaoszczędzić poprzez wspólną ich ochronę. Np. pingwiny chronią się przed zimnem, tworząc zbite grupy. Tego typu działanie to jeden ze sposobów ochrony własnych zasobów. Wyłaniające się nowe możliwości, wzmiankowane przez badaczy, są ważną częścią składową pojęcia synergii (Mesjasz, Szarucki, 2017). Na jakim etapie się one ujawniają?

Kwestię wyłaniających się możliwości może wyjaśnić kontynuacja prezentowanego już eksperymentu z wagą walizkową, w którym brało udział wspomniane już małżeństwo A. Małżeństwo nie mogło wspólnie osiągnąć efektu nacisku na wagę większego niż wyniki indywidualne, dlatego małżonkowie posłużyli się pomysłem-innowacją. Metalowy hak wagi przyczepiono do stalowej balustrady na balkonie. Wspólne pociągnięcie wagi walizkowej lewymi kciukami pozwoliło małżeństwu A osiągnąć wynik 16,2 kg. Udało się zatem osiągnąć wynik lepszy niż suma wyników indywidualnych, które w przypadku małżeństwa A wyniosło $11,7 \mathrm{~kg}(4,1+7,6)$. Małżeństwo A osiągnęło efekt synergiczny, ale związane to było $\mathrm{z}$ zastosowaniem innowacyjnej metody działania. Również ważny był wyznaczony cel, dzięki czemu opracowano strategię działania.

\section{Granice samoorganizacji}

Zgodnie z eksperymentem M. Ringelmanna, wspólne działania powodują mniejszy wspólny wysiłek niż działania indywidualne, a wewnętrzna samoorganizacja ma swoje granice. Co jednak się dzieje, kiedy dąży się do przekroczenia swoich możliwości w ramach starych metod działania, nie stosując innowacji? W przypadku człowieka następuje stan zmęczenia, pojawiają się w pracy błędy. Zaburzenia prowadzą do chaosu. Analogią takiej sytuacji w matematyce, ale także w naukach przyrodniczych, może być zjawisko bifurkacji. W powszechnym rozumieniu jest to rozgałęzienie się jakiejś całości na dwie części, w ujęciu matematycznym, to powstanie chaosu poprzez zmianę niewielkiego parametru w równaniu. Samoorganizacja ma swoje granice, których przejawem jest chaos, powstający w wyniku niewielkich zmian. Powodują one rozpad systemu synergicznego. Jednym ze sposobów przekroczenia tej granicy jest innowacja.

\section{Rysunek 6 Sposoby osiągania efektu synergicznego}

\begin{tabular}{|c|c|}
\hline & nowy byt (innowacja) \\
\hline jest samoorganizacja & $\begin{array}{l}\text { działanie wspólne } \\
\text { (obniżenie wykorzystania energii) }\end{array}$ \\
\hline
\end{tabular}


Synergia ma zatem dwa oblicza. Z jednej strony można oszczędzać zasoby nie przekraczając granicy bifurkacji (granicy chaosu), nie trzeba tworzyć nowych innowacji. Jednostki dążą do oszczędzania swoich zasobów. Druga metoda, to przekroczenie granicy bifurkacji i stworzenie w ramach samoorganizacji nowego, innowacyjnego bytu. Wydaje się jednak, że nowy byt funkcjonuje w określonych granicach.

\section{Synergia w firmie rodzinnej}

Zagadnienie synergii $w$ małej firmie rodzinnej można rozpatrywać z punktu widzenia synergizmu, czyli jej samoorganizacji i samoregulacji oraz oszczędzania zasobów energii zorganizowanej grupy. System firmy dąży do równowagi, gdyż stanowi ona specyficzny społeczny układ otwarty, który w sposób ciągły wymienia energię życiową z otoczeniem. Jednocześnie, członkowie zespołu minimalizują energię swobodną wewnątrz grupy, co jest zgodne z wcześniej opisywanym, szerokim podejściem do praw termodynamiki (Bertalanffy, 1950). Jednym z chronionych zasobów jest też wspólna energia życiowa firmy, będąca sumą energii życiowej poszczególnych osób. W firmach rodzinnych, ze względu na ich wielkość, łatwiej ją dostrzec niż w dużych korporacjach.

Małe grupy ludzkie łatwiej się samoorganizują w oparciu o ograniczone zasoby materialne, finansowe, kompetencyjne, ale również wspólne obszary energii życiowej. Pochodną utrzymywania stabilnego systemu jest ograniczanie zasięgu przestrzennego działalności, działalność w niszy produktowej, zaspokajanie wybranych potrzeb klientów. Dzięki temu firma umacnia się poprzez działalność w bezpiecznej przestrzeni rynkowej. Tego typu firmy mają często związek z cechami osobowościowymi przedsiębiorców. Osoby o spokojnym usposobieniu i skromnym stylu życia skłonne są tworzyć firmy o stabilnym rozwoju działalności i nie- wielkim stopniu ryzyka (Barczak, 2018). Takie podejście pochłania mniej energii życiowej. Jednym z przejawów cech osobowości jest energia wyzwalana przez człowieka albo uzyskiwana $\mathrm{z}$ otoczenia (Bałł, Wilsz, 2015).

Społeczny system firmy, o określonym poziomie wspólnej energii życiowej, utrzymywany jest poprzez istniejące relacje, które go umacniają. Podlegają one bieżącej obserwacji i kontroli. Takie zachowania pozwalają prawidłowo organizować pracę, nie dopuszczać do przekraczania granic dobrej organizacji i wchodzić w strefę chaosu. Spokój i opanowanie są metodami przyczyniającymi się do ochrony wspólnych zasobów energii. Nawiązując do koncepcji synergizmu i funkcjonowania systemów, działającego w firmie człowieka można postrzegać jako jednostkę homeostatyczną (subsystem), funkcjonującą w systemie małej firmy rodzinnej. W określonych sytuacjach wyzwala ona bądź hamuje dopływ własnej energii. Dąży jednocześnie do jej minimalizowania.

Homeostaza fizjologiczna, pojęcie znane $\mathrm{z}$ psychologii, wskazuje na organizm człowieka jako na otwarty system biologiczny będący w kontakcie ze środowiskiem zewnętrznym, utrzymującym własne zasoby energetyczne na określonym poziomie. Wszelkie zakłócenia wewnętrzne lub zewnętrzne prowadzą do uruchamiania mechanizmów regulacyjnych, przystosowujących organizm do nowych stanów lub do stanu pierwotnego (Gasiul, 2007).

W takim ujęciu, synergia $\mathrm{w}$ małej firmie rodzinnej to funkcjonujące homeostatyczne subsystemy w systemie organizacyjnym firmy. Mogą się one samoorganizować, dążąc do oszczędności ograniczonych zasobów, w tym finansowych, kompetencyjnych, rzeczowych i wspólnej energii życiowej. Granicą ich spójnego działania są granice chaosu, a wyjście poza te granice może prowadzić do rozpadu struktury, niekiedy jednak do 
rozwoju, poprzez zastosowanie innowacji różnego typu, w tym produktowych i finansowych. Synergia w firmie rodzinnej może oznaczać ochronę energii życiowej poszczególnych członków rodziny. Właściwie dozowana energia życiowa wpływa na stany emocjonalne i fizjologiczne poszczególnych osób funkcjonujących we wspólnej organizacji.

Energię życiową człowieka można obrazować poprzez skanowanie wybranych obszarów mózgu przy pomocy EEG, czyli zapisu elektroencefalograficznego. Tego typu fale mogą być postrzegane jako suma „pracy” poszczególnych neuronów w mózgu. Wykorzystać można w tym celu urządzenia NeuroSky MindWave Mobile, które stosowane są już w badaniach naukowych. Dzięki NeuroSky można uzyskać obraz mocy sygnału EEG, w tym ocenę rytmów alpha, beta, delta, gamma, theta, obrazowanych na powierzchni głowy. Są one zapisem elektrycznej aktywności mózgu, przedstawiającym potencjał pola elektrycznego wokół neuronów.

Nawiązując do koncepcji synergii i oszczędzania wspólnej energii życiowej małej firmy rodzinnej, wykonano eksperyment pokazujący jak zachowują się rytmy EEG w kontaktach między członkami rodziny.

Rysunek 7 obrazuje zależność między przyjaznym uściskiem między członkami rodziny pracującymi $\mathrm{w}$ firmie. Badano przedział czasowy 120 sekund. Tego typu przyjazny uścisk generuje obniżenie amplitudy fal gamma (częstotliwość 40-200 $\mathrm{Hz}$ ) oraz zmniejszenie amplitudy fal delta (częstotliwość poniżej $4 \mathrm{~Hz}$ ). Reakcje fal EEG pokazują, że członkowie rodziny w ramach synergizmu firmy rodzinnej oddziałują wzajemnie na swoją energię życiową, traktowaną jako wspólny zasób, na bazie którego budowana jest synergia grupy. Wzajemne fizyczne kontakty oddziałują pozytywnie na obserwowane rytmy EEG w mózgu badanych.
Podobne obniżenie intensywności fal gamma, obserwowane w kolejnym eksperymencie przeprowadzonym przez autora, następuje wskutek wykonywania stabilnych prac, w trybie spokojnym i zrównoważonym. Monotonne prace, przy całkowitym spokoju, powodują również obniżenie intensywności fal gamma i delta, podobnie jak w przypadku przyjacielskiego uścisku. Wydaje się zatem, że dążenie do oszczędzania wspólnej energii grupy, poprzez tego typu zachowania, jest jednym $\mathrm{z}$ dowodów na istnienie firmy jako systemu, w którym jego uczestnicy traktują energię życiową jako wspólny, cenny zasób.

\section{Podsumowanie}

Pojęcie synergii jest pojęciem pojemnym. Zawiera kilka kluczowych cech, które powinno ujmować się charakteryzując to pojęcie. Przede wszystkich to wykorzystywanie wspólnych, ograniczonych zasobów, samoorganizowanie w ramach systemu, samoregulacja. Synergia ma swoje granice, a jednym ze sposobów ich przekroczenia są innowacje. Synergii podlegają też małe firmy rodzinne, które chronią swoje zróżnicowane zasoby. Jednym z nich może być wspólna energia życiowa przedsiębiorców, nawiązująca do energii swobodnej, znanej z termodynamiki. Przekraczanie synergicznych granic bifurkacji prowadzi do zaburzeń systemu, utraty jego równowagi, a to niekiedy skutkuje rozpadem i powstawaniem kosztów.

\section{Rysunek 7 Pomiar fal gamma i delta}

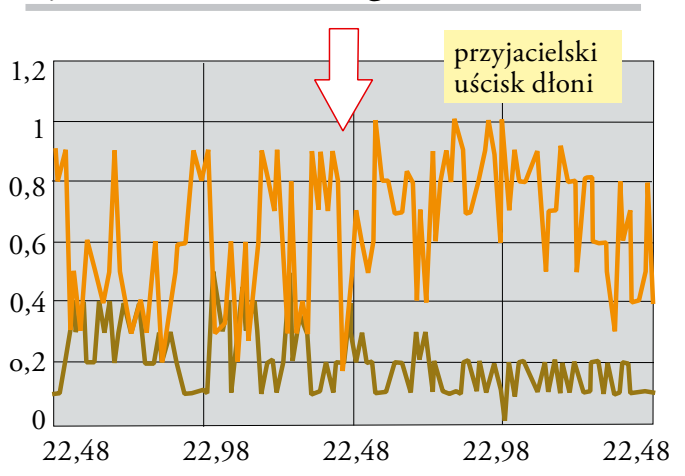

Źródło: opracowanie własne. 


\section{Bibliografia:}

1. Bałł G., Wilsz J. (2015), Koncepcja statych indywidualnych cech osobowości w kontekście racjonalistyczno-humanistycznej metodologii nauk o cztowieku, "Psychological Journal”, Vol. 21(2), p. 151-162.

2. Barczak P. (2018), Mata firma niszowa-próba zdefiniowania, „Kwartalnik Nauk o Przedsiębiorstwie”, nr 2, kwiecień-czerwiec, Oficyna Wydawnicza SGH w Warszawie, Warszawa, s. 24.

3. Bertalanffy L. (1950), The Theory of Open Systems in Physics and Biology, "Science", Vol. 111, Issue 2872.

4. Corning P. (1998), The Synergism Hypothesis: On The Concept Of Synergy And It's Role In The Evolution Of Complex System, "Journal of Social and Evolutionary Systems”, Vol. 21(2).

5. Fuller R.B., Applewhite E.J. (1975), Synergetics: Explorations in the Geometry of Thinking, Macmillan Publishing, p. 59.

6. Gasiul H. (2007), Teorie emocji i motywacji, Warszawa, Wydawnictwo Uniwersytetu K.S. Wyszyńskiego, s. 290.

7. Griffin R.W. (2006), Podstawy zarządzania organizacjami, Warszawa, PWN, s. 56.

8. Haken H. (1983), Advanced Synergetics. Istability Hierarchies of Self Organizing Systems and Devices, Springer-Verlag, p. 2-8.

9. Haken H. (1996), Principles of Brain Functioning, A Synergetic Approach to Brain Activity, Behavior and Cognition, Springer-Verlag.

10. Jędrusiak M. (2017), Eksperymentalne i modelowe badanie dynamicznych niestabilności w reakcjach chemicznych z udziatem nadtlenku wodoru, praca doktorska, UW, Warszawa.

11. Krawczyk S. (2011), Logistyka. Teoria i praktyka. Tom 1, Warszawa, Difin, s. 35.

12. Latash M.L. (2008), Synergy, Oxford University Press, p. 13-15.

13. Leland H.E. (2007), Financial Synergies and the Optimal Scope of the Firm: Implications for Mergers, Spinoffs, and Structured Finance, "The Journal of Finance", Vol. LXII, No. 2.

14. Leszczewska K., Sobiecki R. (2011), Przedsiębiorstwa rodzinne wobec sytuacji kryzysowych, Studia i Analizy Instytutu Przedsiębiorstwa, Determinanty rozwoju przedsiębiorczości w Polsce, s. 293-314.

15. Mesjasz C., Szarucki M. (2017), Synergia i przewidywanie w strategii fuzji i przejęć, Studia Oeconomica Posnaniensia, Vol. 5, No. 9.

16. Ringelmann M. (1913), Recherches sur les moteurs animés: Travail de l'homme, Institut National Agronomique, Paris.

17. Skowrońska A., Tarnawa A. (2018), Raport o stanie sektora matych i średnich przedsiębiorstw w Polsce, PARP, grupa PFR, Warszawa.

18. Turvey M.T., Carello C. (1996), Dynamics of Berstein's Level of Synergies, Latash M.L., Turvey M.T. (ed.), New Jersey, Lawrence Erlbaum Associates, p. 9-12, 339-376.

19. Vijay M., Wind Y. (1988), Business synergy Does Not Always Pay Off, "Long Range Planning”, Vol. 21, No. 1, p. 59-65.

20. Williams K, Harkins S., Latane B. (1981), Identifiability as a Deterrent to Social Loafing: Two Cheering Experiments, "Journal of Personality and Social Psychology”, Vol. 40, No. 2, p. 303-311.

21. Zieleniewski J. (1982), Organizacja zespotów ludzkich. Wstęp do teorii organizacji i kierowania, PWN, Warszawa, s. 313.

Dr inż. Piotr Barczak, przedsiębiorca, doktorant, Szkoła Główna Handlowa w Warszawie 